\title{
Status Epilepticus-Induced Alterations in Metabotropic Glutamate Receptor Expression in Young and Adult Rats
}

\author{
Eleonora M. Aronica, Jan A. Gorter, Marie-Christine Paupard, Sonja Y. Grooms, Michael V. L. Bennett, and \\ R. Suzanne Zukin \\ Department of Neuroscience, Albert Einstein College of Medicine, Bronx, New York 10461
}

\begin{abstract}
In adult rats, kainic acid induces status epilepticus and delayed, selective cell loss of pyramidal neurons in the hippocampal CA3. In pup rats, kainate induces status epilepticus but not the accompanying neuronal cell death. The precise mechanisms underlying this age-dependent vulnerability to seizure-induced cell death are not understood. Metabotropic glutamate receptors (mGluRs) are developmentally and spatially regulated throughout the hippocampus and are implicated in seizureinduced damage. In the present study we used in situ hybridization to examine possible changes in mGluR expression at the level of the hippocampus after status epilepticus in postnatal day 10 (P10) pup and adult (P40) rats. Status epilepticus did not alter expression of mGluR1, mGluR3, or mGluR5 mRNAs. In pup and adult rats, status epilepticus induced a reduction in expression of mGluR2 mRNA in granule cells of the
\end{abstract}

dentate gyrus. This change could lead to augmented glutamate release at mossy fiber synapses on CA3 pyramidal cells and thereby promote hyperexcitation. In pup but not adult rats, mGluR4 mRNA expression was enhanced in CA3 pyramidal neurons. Upregulation of presynaptic mGluR4 in pup CA3 neurons could lead to reduced transmitter release from CA3 axons, including recurrent collaterals, thereby reducing vulnerability of neonatal CA3 neurons to seizure-induced damage. These findings indicate that status epilepticus affects mGluR expression in a gene- and cell-specific manner, and that these changes vary with the developmental stage.

Key words: metabotropic glutamate receptors; receptor mRNAs; development; hippocampus; status epilepticus; seizures; epilepsy
Glutamate neurotoxicity is thought to play a critical role in the mechanisms underlying neuronal cell death after severe seizure activity (Choi, 1994; Meldrum, 1993; for review, see Meldrum, 1995). A primary event in seizure-induced cell death within the hippocampus is excessive release of glutamate leading to a large rise in intracellular $\mathrm{Ca}^{2+}$ (Dingledine et al., 1990; Choi, 1992, 1994; Meldrum, 1993). Glutamate can increase intracellular $\mathrm{Ca}^{2+}$ by direct $\mathrm{Ca}^{2+}$ flux through ionotropic glutamate receptors (NMDA receptors, AMPA receptors lacking the GluR2 subunit, and kainate receptors assembled from unedited subunits), depolarization leading to activation of voltage-sensitive $\mathrm{Ca}^{2+}$ channels, and activation of metabotropic glutamate receptors (mGluRs) leading to release of $\mathrm{Ca}^{2+}$ from intracellular stores. In vivo studies suggest a role for mGluRs in epileptogenesis and seizure-induced damage (for review, see Schoepp and Conn, 1993; Nicoletti et al., 1996). Activation of phosphatidyl inositollinked (group I) mGluRs (mGluR1 and mGluR5) increases neuronal excitability and facilitates NMDA-dependent long-term potentiation (McGuinness et al., 1991; Behnisch and Reymann,

Received May 13, 1997; revised Aug. 18, 1997; accepted Aug. 20, 1997.

This work was supported by National Institutes of Health Grants NS 20752 and NS 31282 (R.S.Z.), NS 07412 (M.V.L.B.), Aaron Diamond postdoctoral fellowship awards (E.M.A. and M.-C.P.), and a Human Frontiers Science Program award (to J.A.G) S.Y.G. is an American Psychological Association Minority Fellow in Neuroscience (National Institutes of Health Grant MH 18882). M.V.L.B. is the Sylvia and Robert S Olnick Professor of Neuroscience. We thank C. Roy for excellent histological preparations and Thoralf Opitz for helpful comments with this manuscript.

Correspondence should be addressed to Dr. R. Suzanne Zukin, Department of Neuroscience, Albert Einstein College of Medicine, 1300 Morris Park Avenue, Bronx, NY 10461.

Dr. Aronica's and Dr. Gorter's present address: University of Amsterdam, Department of Experimentele Dierkunde, Kruislaan 320, 1098 SM Amsterdam, The Netherlands.

Copyright (C) 1997 Society for Neuroscience $\quad 0270-6474 / 97 / 178588-08 \$ 05.00 / 0$
1993), presumably by release of $\mathrm{Ca}^{2+}$ from intracellular stores and potentiation of ionotropic glutamate receptors. Activation of group I mGluRs induces limbic seizures and causes selective neuronal degeneration, primarily in the hippocampal CA3 (Tizzano et al., 1993). Damage is attenuated by group I mGluR antagonists and blockers of intracellular $\mathrm{Ca}^{2+}$ mobilization, but not by antagonists of ionotropic glutamate receptors. In contrast, agonists of group II/III mGluRs protect against seizures (Gereau and Conn, 1995; Tizzano et al., 1995; Miyamoto et al., 1997). Moreover, activation of mGluR2/3 attenuates neuronal cell death induced by hypoxia combined with glucose deprivation in an in vitro model for ischemic neuronal damage (Buisson and Choi, 1995). Cellular mechanisms implicated in this neuroprotective action include inhibition of cAMP formation, inhibition of voltage-sensitive $\mathrm{Ca}^{2+}$ channels, and inhibition of glutamate release (Lanthorn et al., 1984; Manzoni and Bochaert, 1995; for review, see Nicoletti et al., 1996).

In situ hybridization and mGluR2 immunolabeling after dentate gyrus lesions indicate that mGluR2 is predominantly expressed in dentate gyrus granule cells and selectively distributed to mossy fibers (Ohishi et al., 1993; Shigemoto et al., 1995). Immunoelectron microscopy indicates localization of mGluR2 protein at the preterminal zone of mossy fibers, where it is postulated to mediate inhibition of glutamate release (Shigemoto et al., 1995; Yokoi et al., 1996). mGluR4 is expressed prominently in the enthorinal cortex and cerebellum and at low levels in the hippocampal CA2, where it is thought to mediate heterosynaptic inhibition of glutamate release at pyramidal axon terminals (Ohishi et al., 1995; Bradley et al., 1996; Kinoshita et al., 1996) (R. Shigemoto, personal communication).

The present study was undertaken to examine possible changes 

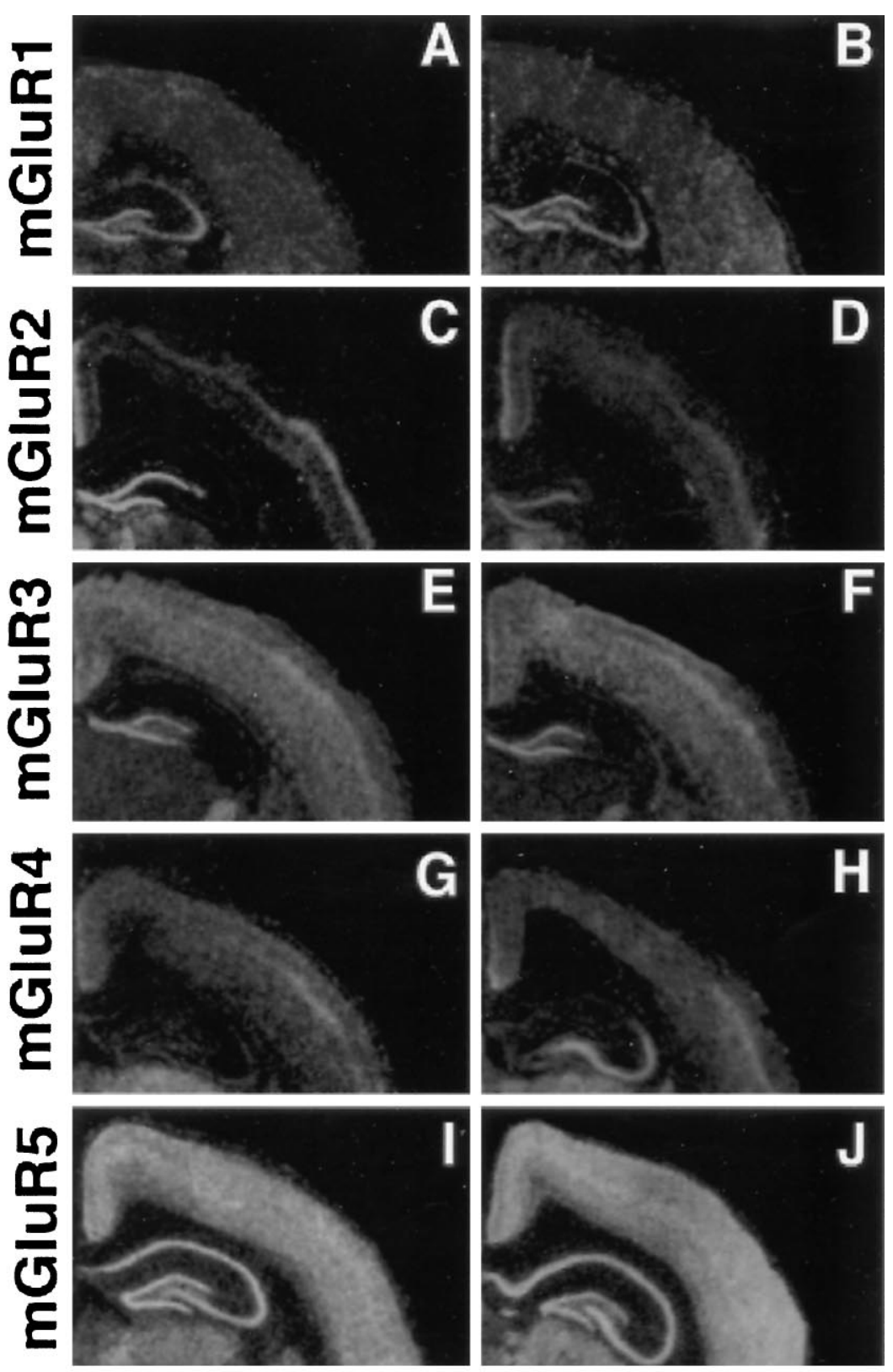

\section{Control}

\section{Status Epilepticus}

Figure 1. Status epilepticus-induced changes in mGluR2 and mGluR4 mRNA expression in P10 pup rats. Film autoradiograms of in situ hybridization in coronal sections at the level of the hippocampus of control and status epilepticus pups $24 \mathrm{hr}$ after the onset of seizures. mGluR2 mRNA expression was prominent in the DG granule cell layer of control pups but was markedly decreased in the granule cell layer of status epilepticus animals $(C, D)$. mGluR4 mRNA expression was at near background levels in the CA3 pyramidal cell layer of control pups but was prominent in the CA3 of status epilepticus pups $(G, H)$. Control sections are shown on the left; experimental sections are shown on the right. mGluR1, mGluR3, and mGluR5 mRNAs were not detectably altered in any region after status epilepticus $(A, B, E, F, I, J)$. in mGluR gene expression in the hippocampus after status epilepticus in young [postnatal day 10 (P10)] and adult rats (P40). We find that status epilepticus leads to differential changes in mGluR mRNA expression at the two ages. mGluR2 mRNA expression is reduced in the dentate gyrus by $24 \mathrm{hr}$ after induction of seizures in both pup and adult rats. This change could lead to augmented glutamate release at mossy fiber synapses on CA3 pyramidal cells. In contrast, mGluR4 mRNA expression is upregulated in the CA3 of pup rats only. This change could lead to reduced transmitter release by $\mathrm{CA} 3$ axons, including recurrent collaterals. Upregulation of mGluR4 mRNA expression in CA3 pyramidal neurons after status epilepticus may be a contributing factor to the lesser vulnerability of neonatal CA3 neurons to seizure-induced damage.

\section{MATERIALS AND METHODS}

Kainic acid administration. Pup (P10) and male adult (P40) Wistar rats (Charles River, Wilmington, MA) were maintained in a temperatureand light-controlled environment with a 14/10 hr light/dark cycle. Animals were treated in accordance with the principles and procedures of the National Institutes of Health Guidelines for the Care and Use of Laboratory Animals. For status epilepticus studies, experimental animals received a single intraperitoneal injection of kainic acid (P10 rats, 2 $\mathrm{mg} / \mathrm{kg}$; P40 rats, $12.5 \mathrm{mg} / \mathrm{kg}$; Sigma, St. Louis, MO). Paired control rats were injected with PBS. All rats were monitored for behavioral manifestations of status epilepticus for at least $3 \mathrm{hr}$ after treatment. Only rats that exhibited status epilepticus, defined as clonic-tonic seizure activity for a minimum of $1 \mathrm{hr}$ ( 20 of 32 pup rats of which six died) or continuous seizure activity for a minimum of $1.5 \mathrm{hr}$ (10 of 10 adult rats, one of which 


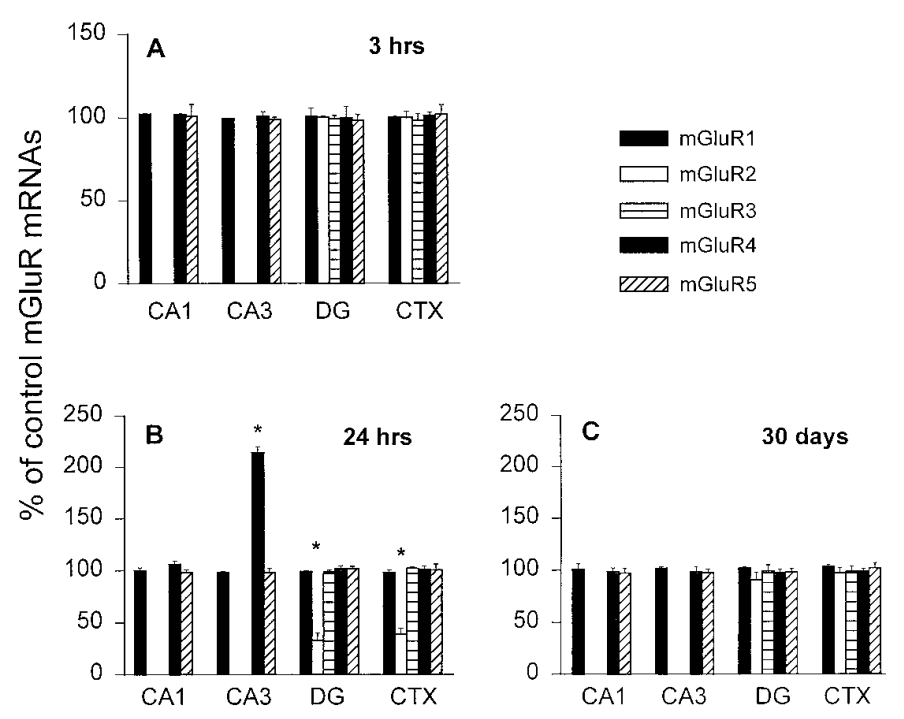

Figure 2. Quantitative analysis of status epilepticus-induced changes in expression of metabotropic glutamate receptor mRNAs (mGluR1-5) in hippocampus of pup rats. Data indicate the mean densities of autoradiographic films for in situ hybridization of mGluR1-5 in CA1, CA3, and DG at the level of the dorsal hippocampus at $3 \mathrm{hr}(A) 24 \mathrm{hr}(B)$ and $30 \mathrm{~d}(C)$ after the onset of status epilepticus in P10 pup rats. $A$, At $3 \mathrm{hr}$ after the onset of status epilepticus, mGluR1-5 expression did not differ significantly from that of control animals. $B$, At $24 \mathrm{hr}$ after the onset of status epilepticus, mGluR2 mRNA expression was significantly decreased in the DG granule cell layer of status epilepticus pups relative to that of controls; mGluR4 mRNA expression was significantly increased in the CA3 pyramidal cell layer. $C$, By $30 \mathrm{~d}$ after the onset of status epilepticus, mGluR2 mRNA expression in DG and mGluR4 expression in CA3 were at control values. mGluR1, mGluR3, and mGluR5 mRNA expression levels were unchanged at all times examined. Error bars indicate SE $(n=6)$. *Statistical significance at a level of $p<0.01$, as determined by the Student's unpaired $t$ test. Density readings for mGluR1-5 mRNAs were made over the depth of the cell body layer of each subfield, CA1, CA3, and DG, at the level of the dorsal hippocampus. Data indicate the mean densities of autoradiographic films for a given subfield taken from a minimum of three consecutive sections of each of six animals per time point. Averaged film densities corresponding to expression of mGluR1-5 mRNAs for each hippocampal subfield in control rats were corrected for film backgrounds and are defined as $100 \%$. SEMs for a given probe and subfield at each time point were $<5 \%$.

died), were used in the study. Pup rats were returned to the lactating mother until they were killed.

Histology. In independent control experiments, neuronal damage was assessed in brain sections of P40 animals by histological examination 24 and $72 \mathrm{hr}$ after injection of kainic acid ( $n=4$ at each time point) or PBS ( $n=4$ at each time point). Animals were anesthetized with ether and decapitated. Brains were removed and placed in ice-cold PBS. Hippocampi were dissected rapidly and sectioned into thick transverse slices $(1 \mathrm{~mm})$ with a McIlwain tissue chopper. Slices were transferred to ice-cold fixative $(2.5 \%$ glutaraldehyde and $4 \%$ formaldehyde in $0.1 \mathrm{M}$ sodium cacodylate buffer, $\mathrm{pH} 7.4)$. After fixation $\left(4^{\circ} \mathrm{C}\right.$ overnight), tissue was osmicated $\left(2 \% \mathrm{OsO}_{4}\right.$ in $0.1 \mathrm{~m}$ sodium cacodylate buffer, $\left.\mathrm{pH} 7.4,2 \mathrm{hr}\right)$, dehydrated, and embedded in Eponate 12 resin (Ted Pella Inc., Redding, CA). Thin sections $(2 \mu \mathrm{m})$ were cut and stained with toluidine blue. In addition, emulsion-dipped sections that had been subjected to in situ hybridization were counterstained with hematoxylin and eosin.

In situ hybridization. The experimental methods used for in situ hybridization were as described by Pellegrini-Giampietro et al. (1991). Animals were anesthetized with ether and decapitated. Brains were rapidly removed, frozen by immersion in 2 -methylbutane at $-35^{\circ} \mathrm{C}$, and sectioned on a cryotome $(20 \mu \mathrm{m})$. [ ${ }^{35}$ S] uridine triphosphate (UTP)-labeled RNA probes were transcribed from mGluR1 (1363 bp EcoRI-SacI fragment of pmGR1; Shigemoto et al., 1992), mGluR2 (616 bp ApaI-SacI fragment of pmGR2; Ohishi et al., 1994), mGluR3 (1464 bp HindII-XbaI fragment of pmGR3), mGluR4 (1230 bp XhoI-
PstI fragment of pmGR4; Tanabe et al., 1992), and mGluR5 (1824 bp BglI fragment of pmGR5; Abe et al., 1992) cDNAs. The probes used in this study are "pan" probes, in that they do not discriminate among mGluR splice variants (Pin et al., 1992; Tanabe et al., 1992; Simoncini et al., 1993). After fixation with $4 \%$ paraformaldehyde in PBS, sections were dehydrated in ethanol, dried at room temperature, and stored at $-70^{\circ} \mathrm{C}$ until use. Before application of riboprobes, slides were incubated $\left(2 \mathrm{hr}\right.$ at $\left.50^{\circ} \mathrm{C}\right)$ with $100 \mu \mathrm{l}$ of prehybridization solution [50\% $(\mathrm{w} / \mathrm{v})$ formamide, $2.5 \times$ Denhardt's solution, $4 \times \mathrm{SSC}, 10 \mathrm{~mm}$ Tris- $\mathrm{HCl}$, $1 \mathrm{~mm}$ EDTA, $0.05 \%$ SDS, $150 \mu \mathrm{g} / \mathrm{ml}$ herring sperm DNA, and 50 $\mu \mathrm{g} / \mathrm{ml}$ total yeast RNA] per section. Sections were then hybridized under stringent conditions (prehybridization solution containing $10 \%$ dextran sulfate, $10 \mathrm{~mm}$ dithiothreitol, and $4 \times \mathrm{SSC}, 58^{\circ} \mathrm{C}, 5 \mathrm{hr}$ ) with ${ }^{35} \mathrm{~S}$-labeled riboprobe $\left(10^{6} \mathrm{cpm} / \mathrm{section}, 1 \mathrm{ng} / \mathrm{l}\right)$. Sections were washed, treated with RNase A $(20 \mu \mathrm{g} / \mathrm{ml})$, and dehydrated in ethanol. Slides were apposed to Kodak (Rochester, NY) XAR-5 film for 48-96 hr or, for higher resolution studies, dipped in photographic emulsion (Kodak NTB-2) and exposed for 1-4 weeks. The anatomy of brain images were assessed from autoradiographs and verified in hematoxylin-eosinstained sections by reference to the atlas of Paxinos and Watson (1984). Microscopic examination was performed for every hippocampal region described. Photomicrographs were obtained using a Nikon Labophot and bright-field optics.

Signal specificity. Signal specificity was assessed in two ways. (1) Competition experiments, in which radiolabeled probes were hybridized to sections in the presence of excess (100-fold) unlabeled probe, resulted in virtually blank autoradiograms. Accordingly, identical labeling patterns were observed when labeled mGluR1 to five probes were each incubated alone and with an excess of the other mGluR unlabeled probes, indicating that conditions were of sufficiently high stringency to rule out crosshybridization among mGluR1-5. (2) In separate control studies, labeling by sense or antisense RNA probes to sections pretreated with RNase A $(100 \mu \mathrm{g} / \mathrm{ml})$ showed no detectable labeling.

Quantitation. For quantitation of mRNA expression levels, autoradiograms were analyzed with a Molecular Dynamics (Sunnyvale, CA) $300 \mathrm{~A}$ computing densitometer using National Institutes of Health IMAGE 1.52 image-processing and analysis software. This program computes the area and mean gray value of a selected image or brain region. Films were scanned at 2000 dpi resolution, and images of each section $\left(\sim 1 \times 10^{6}\right.$ pixels $)$ were created. Gray values were corrected for background and computed for indicated regions in three consecutive sections from each animal, normalized to optical density values for the same probe and the same region in sections from controls, and expressed as grand means ( \pm SEMs). Averaged densities were computed for the following hippocampal subfields: (1) the CA1 pyramidal cell layer; (2) the CA3 pyramidal cell layer; and (3) the granule cell layer of the dentate gyrus (DG). Pixel size was small compared with structures examined. To enable comparisons between groups for any given probe, corresponding brain sections from status epilepticus and control rats of a given age were cut in the same experimental session, incubated with the same solutions of RNA probe on the same day, and apposed to the same sheet of film. Although experiments were not performed blinded, changes in mGluR 2 and mGluR4 expression were sufficiently pronounced as to be obvious in all sections examined from experimental and control animals.

Statistical analyses. Changes in optical density for kainate-injected rats exhibiting status epilepticus were expressed as percent of optical density values for corresponding regions of control rat brain within the same film. Mean optical density readings were statistically analyzed by the Student's unpaired $t$ test $(p<0.01)$. The rationale of the quantitative analysis was based on the following factors: (1) for a particular probe, optical density readings taken from each region of interest varied little in different sections from the same animals; (2) the concentration of RNA probe used $\left(10^{6} \mathrm{cpm} /\right.$ section $)$ produced saturating levels of hybridization and the maximal signal-to-noise ratio; and (3) use of $\left[{ }^{35}\right.$ S]UTP-labeled brain paste standards indicated that exposure times were in the linear response range of the film (Pellegrini-Giampietro et al., 1991).

\section{RESULTS}

\section{Behavioral manifestations of status epilepticus differ in P10 and P40 rats}

Administration of kainic acid by intraperitoneal injection $(2 \mathrm{mg}$ / $\mathrm{kg}$ ) induced status epilepticus in 20 of $32 \mathrm{P} 10$ pups $(62.5 \%) ; 12$ 

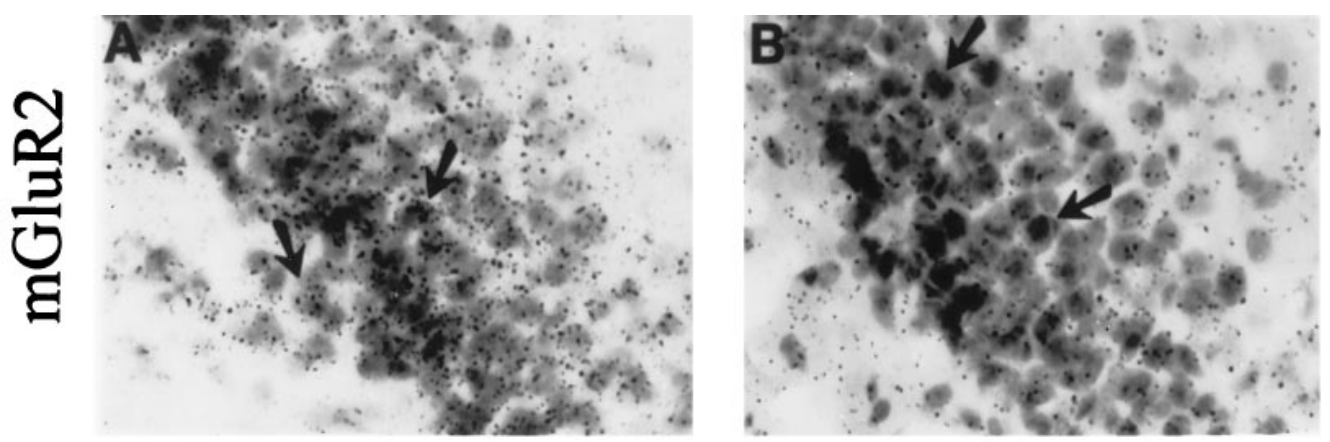

\section{DG}

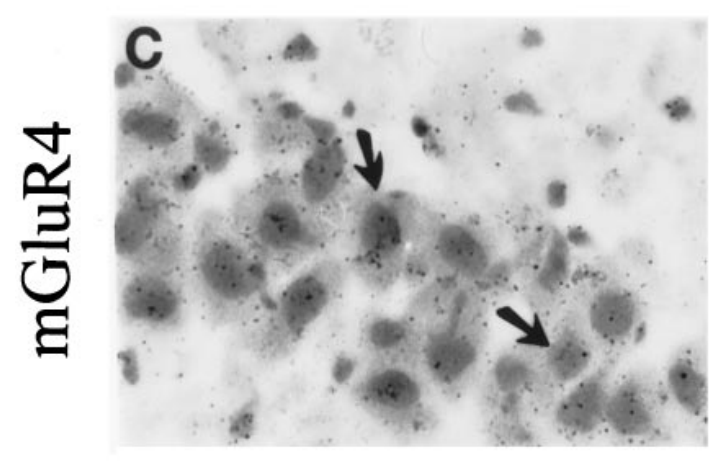

Control

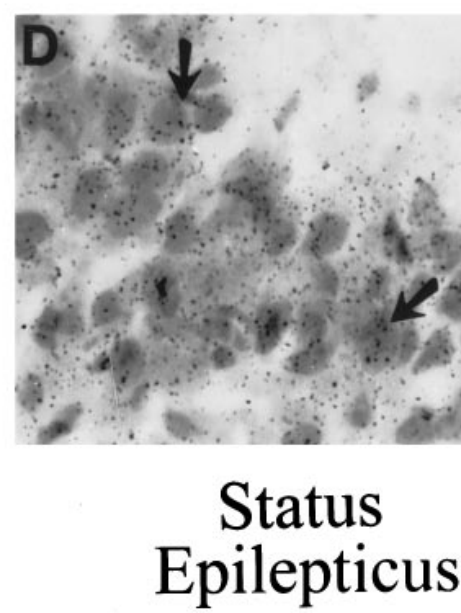

Figure 3. Emulsion-dipped sections showing expression of mGluR2 mRNA in the granule cell layer of the dentate gyrus and mGluR4 mRNA in the CA3 pyramidal cell layer in coronal sections of control $(A, C)$ and status epilepticus $(B, D)$ P10 pup rats at 24 hr after onset of seizures. Photomicrographs of emulsion-dipped slides showing in situ hybridization silver grains overlying individual neurons. Emulsion-dipped sections were counterstained with hematoxylin and eosin. $A, B$, mGluR2 hybridization grains overlying individual DG cells were reduced after status epilepticus relative to labeling in DG of control brain. $C, D$, mGluR4 mRNA expression in CA3 pyramidal cells exhibited increased hybridization grains per cell (arrows) relative to control. Arrows indicate clusters of silver grains on cell bodies of granule cells for mGluR2 or CA3 pyramidal cells for mGluR4 mRNA. Scale bar, $30 \mu \mathrm{m}$.

pups exhibited mild seizures and were not studied further. Fourteen of the 20 status epilepticus pups survived. Hallmarks of bilateral status epilepticus at this age are continuous hindlimb scratching, followed by swimming-like movements and prolonged tonic-clonic seizures (see Tremblay et al., 1984). The onset of tonic-clonic status epilepticus occurred within $30 \mathrm{~min}$ after kainic acid injection. Seizures lasted at least $1 \mathrm{hr}$. At P40, all 10 kainate-injected $(12.5 \mathrm{mg} / \mathrm{kg})$ rats experienced severe seizures. The onset of seizures occurred just over $1 \mathrm{hr}$ after kainate injection. Rats exhibited generalized seizures, including repetitive rearing, jumping, and loss of postural control. Seizures were accompanied by strong salivation and foaming at the mouth. In 8 of 10 rats $(80 \%$, one of which died), seizures lasted $>2 \mathrm{hr}$. In two rats, seizures lasted 1.5-2 hr. After several hours, the severity of seizures declined.

\section{In P10 rat pups, status epilepticus decreases mGluR2 mRNA and increases mGluR4 mRNA expression in hippocampus}

To examine patterns of metabotropic glutamate receptor mRNA expression in hippocampus after status epilepticus, in situ hybridization was performed on sections of control P10 rats and kainate-injected P10 rats that survived status epilepticus at 3 and $24 \mathrm{hr}$ and $30 \mathrm{~d}$ after the onset of seizures. In control pups, GluR1-5 exhibited cell-specific patterns of expression throughout the hippocampus and neocortex in accordance with previous studies (Catania et al., 1994; Ohishi et al.,
1994). Changes in receptor expression were assessed quantitatively by computerized image analysis of autoradiographic film densities. Changes in expression were observed only for mGluR2 and mGluR4 mRNA in specific regions at $24 \mathrm{hr}$ after the onset of status epilepticus (Figs. 1, 2). mGluR2 mRNA expression was markedly reduced in the granule cell layer of the dentate gyrus (to $33 \pm 7 \%$ of control; $p<0.01 ; n=6$ for status; $n=6$ for controls) (Figs. $1 C, D, 2$ ). mGluR2 was also decreased in the parietal cortex (averaged across all cell layers) at the level of the dorsal hippocampus, but the change in expression level density did not reach statistical significance (data not illustrated). mGluR4 expression was markedly increased in the hippocampal CA3 (to $214 \pm 6 \%$ of control) (Figs. $1 G, H, 2$ ). The changes in mGluR2 and mGluR4 mRNA expression were transient; at $30 \mathrm{~d}$ after the onset of seizures, expression had returned to near control values (differences from control values were not significant). Expression of mGluR4 mRNA was unchanged in other brain regions examined (e.g., parietal cortex 1). mRNAs encoding mGluR1, mGluR3, and mGluR5 receptors were unchanged at 3 and 24 hr and at $30 \mathrm{~d}$ after the onset of seizures.

\section{Status epilepticus-induced changes in mGluR2 and mGluR4 expression at the cellular level in $P 10$ rats}

Microscopic localization of status epilepticus-induced changes in metabotropic glutamate receptor mRNA was achieved by 

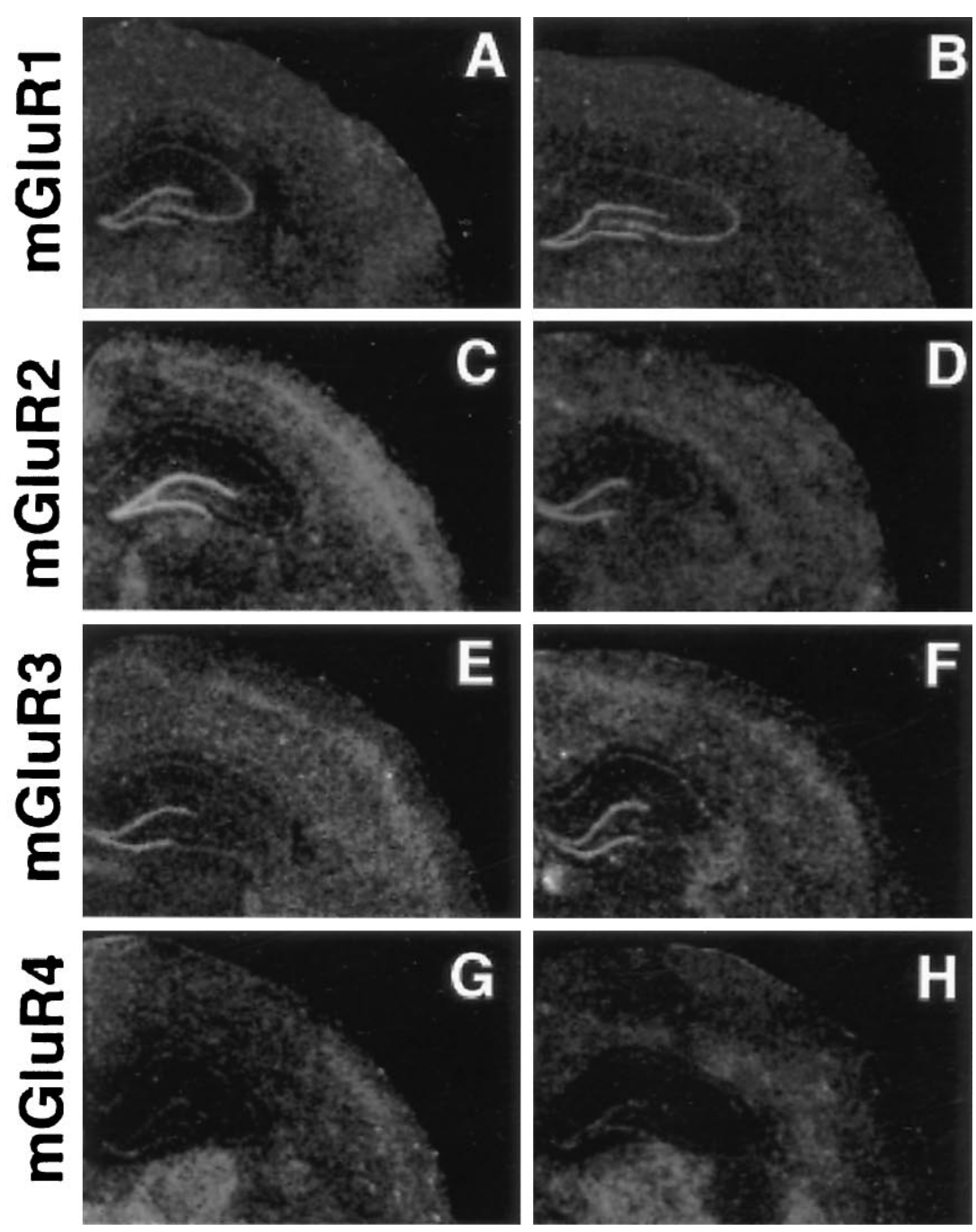

Figure 4. Expression of mGluR1-5 mRNAs in adult rat hippocampus $24 \mathrm{hr}$ after onset of kainate-induced status epilepticus. As in P10 animals, mGluR2 mRNA expression was markedly decreased in the dentate gyrus of experimental animals $(D)$ relative to that of control brain (C). mGluR1, mGluR3, mGluR4, and mGluR5 mRNAs were not detectably altered in any hippocampal subfield at all times examined. Left, Control animals; right, experimental animals.

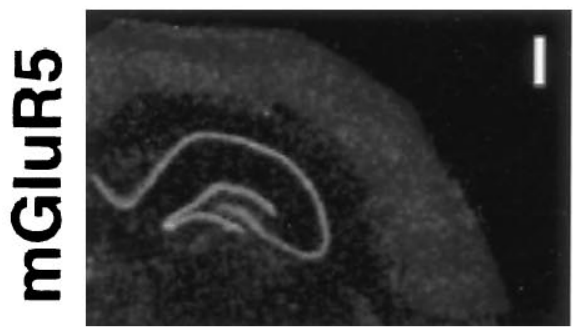

\section{Control}

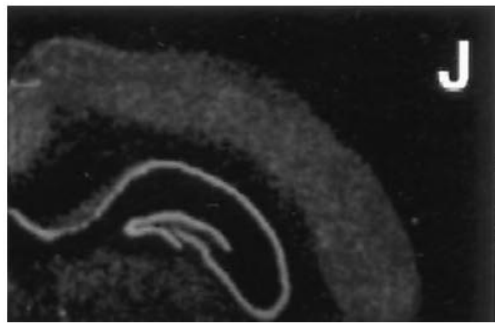

\section{Status Epilepticus}

analysis of emulsion-dipped sections of P10 rat brain. Brightfield microscopy revealed that expression of mGluR2 within the hippocampus was localized to granule cells of the dentate gyrus. At $24 \mathrm{hr}$ after induction of seizures, the density of hybridization grains overlying individual granule cells was decreased for experimental compared with control animals (Fig. 3A,B). This finding indicates that the downregulation of mGluR2 mRNA observed in film autoradiographs is attributable to a decrease in the quantity of transcript per cell. In contrast, examination of sections labeled with the mGluR4 probe revealed an increased density of grains overlying indi- vidual pyramidal neurons in the CA3 in experimental versus control P10 brain, indicative of increased mRNA expression per neuron (Fig. 3C,D).

\section{In adult rats, status epilepticus decreases expression of mGluR2 mRNA but does not increase expression of mGluR4 mRNA}

To examine patterns of mGluR1-5 receptor mRNA expression in hippocampus after status epilepticus in adult rats, in situ hybridization was performed on sections of control and kainate-injected young adult (P40) rat brain. Expression patterns in control adult 


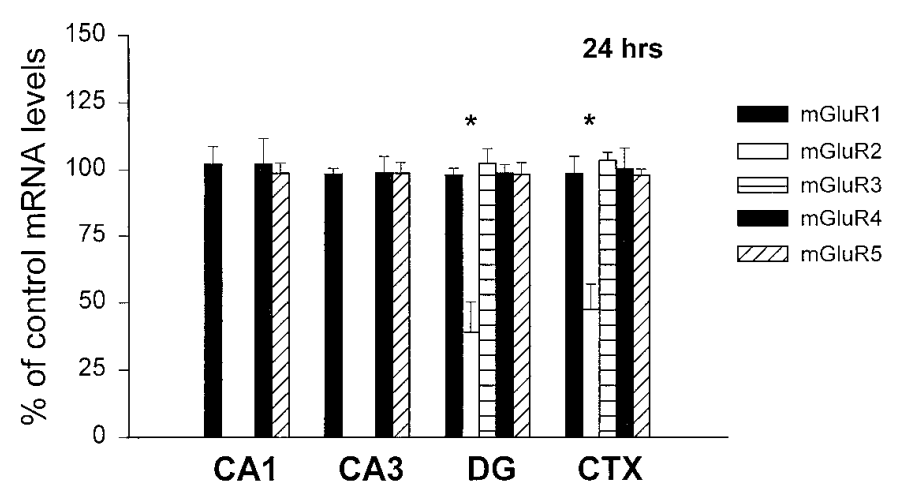

Figure 5. Quantitation of mGluR1-5 mRNA expression in hippocampal subfields (CA1, CA3, and DG) $24 \mathrm{hr}$ after the onset of status epilepticus in P40 (adult) rats. mGluR2 mRNA was markedly reduced in the dentate gyrus; expression of mGluR1, mGluR3, mGluR4, and mGluR5 mRNAs was unaltered. Values reported are film densities for a given area expressed as percent density of those in the corresponding subfields of control animals. Error bars indicate SE for six experimental and six control rats. ${ }^{*} p<0.01$, Student's unpaired $t$ test.

rats were in accordance with previous studies (Catania et al., 1994; Ohishi et al., 1994). Status epilepticus induced marked decreases in mGluR2 mRNA expression in the granule cell layer of the dentate gyrus at $24 \mathrm{hr}$ after the onset of seizures (Fig. $4 C, D)$. Densitometric readings revealed that mGluR2 mRNA was decreased in the dentate gyrus to $39 \pm 11 \%$ of control values (status, $n=6$; controls, $n=6$; $p<0.01$ ) (Fig. 5). Examination of emulsion-dipped sections indicated that within the hippocampus, changes in mGluR2 mRNA expression were localized to granule cells. Moreover, hybridization grains overlying virtually all granule cells were reduced in number, indicative of decreased mRNA per neuron (Fig. 6). Expression of mGluR1, mGluR3, mGluR4, and mGluR5 mRNA was not changed in any hippocampal region examined (Figs. 4, 5).

\section{Status epilepticus induces neurodegeneration in adult but not pup rats}

To assess neuronal loss after induction of status epilepticus, brain sections of experimental and control P40 rats were subjected to histological analysis. Toluidine blue-stained sections at the level of the dorsal hippocampus revealed no detectable cell loss at $24 \mathrm{hr}$ after status epilepticus in the CA1 and CA3 pyramidal cell layers (Fig. $7 B, E$ ). In contrast, analysis of brain sections from animals 72 hr after status epilepticus revealed virtually complete loss of neurons in the pyramidal cell layer of the hippocampal CA3 (Fig. $7 F$ ). At $\mathrm{P} 10$, status epilepticus induced no cell loss in any region or at any time examined ( $24 \mathrm{hr}$ and $30 \mathrm{~d}$ ) after status epilepticus (data not illustrated). These age-related differences in patterns of neurodegeneration observed in status epilepticus rats confirm previous studies of Ben-Ari (1985) and Sperber et al. (1991).

\section{DISCUSSION}

The present study shows that status epilepticus induces changes in metabotropic glutamate receptor gene expression that are spatially and temporally regulated. In pup and adult rats, status epilepticus induces a reduction in expression of $\mathrm{mGluR} 2$ receptor mRNA in granule cells of the dentate gyrus. mGluR2 is localized to the preterminal zone at mossy fiber $\rightarrow$ CA3 synapses (Shigemoto et al., 1995; Yokoi et al., 1996). Thus, downregulation of mGluR2 would be expected to result in enhanced glutamate release at mossy fiber $\rightarrow$ pyramidal CA3 synapses, thereby promoting hyperexcitation (see below). In pup but not adult rats, expression of mGluR4 mRNA is enhanced in hippocampal CA3 pyramidal neurons. Within the hippocampus, mGluR4 is localized to the terminus of pyramidal axons, where it is thought to inhibit the release of glutamate (Bradley et al., 1996; Kinoshita et al., 1996) (R. Shigemoto, personal communication). Upgregulation of mGluR4 could lead to reduced transmitter release from CA3 axons, including recurrent collaterals, and thereby contribute to the lesser vulnerability of neonatal CA3 neurons to seizureinduced damage (see below). Interestingly, expression of mGluR4 mRNA is also selectively upregulated in the CA1 and CA3 of the hippocampus after global ischemia (Iversen et al., 1994). Expression of mRNAs encoding other mGluR transcripts (mGluR1, mGluR3, and mGluR5) is unchanged after seizures. Although in this study we measured mRNA and not receptor protein expression, these findings suggest that status epilepticus regulates expression of mGluR2 and mGluR4 receptors in a cell-specific manner and that the changes in mGluR4 vary with
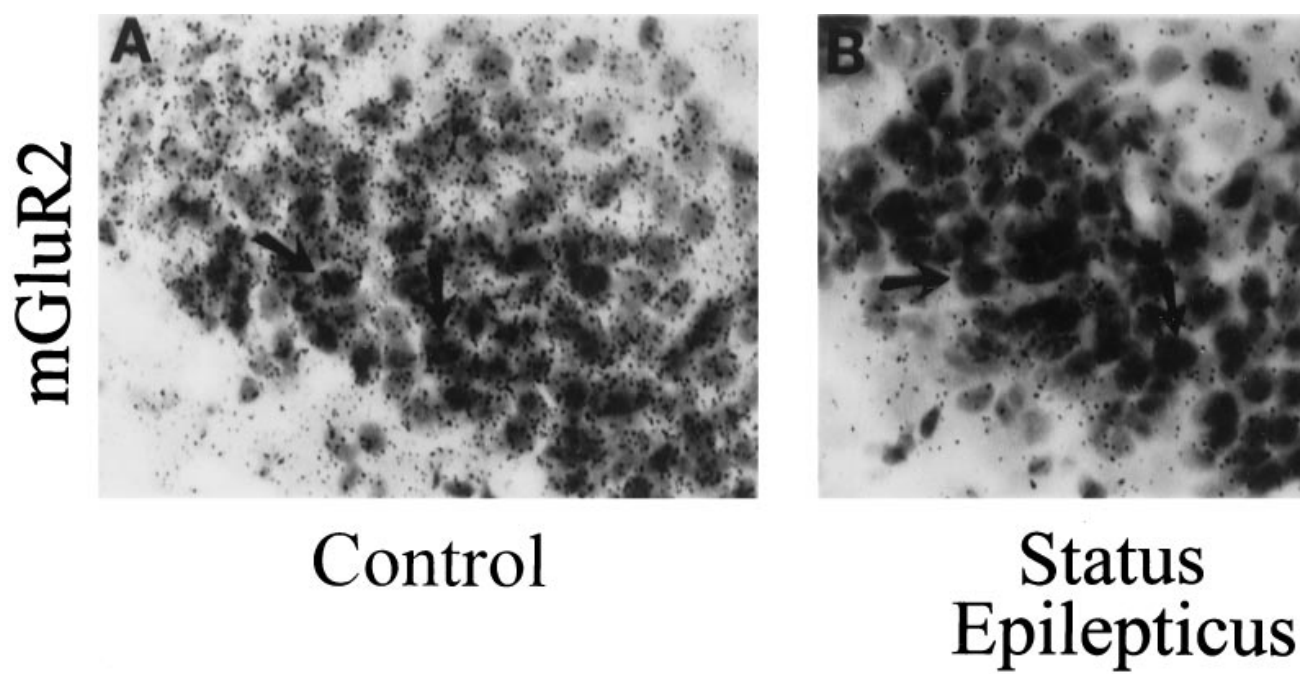

Figure 6. Changes in mGluR2 mRNA per dentate granule cell $24 \mathrm{hr}$ after onset of status epilepticus in adult rats. Photomicrographs of emulsion-dipped sections showing in situ hybridization grains over individual neurons, counterstained with hematoxylin and eosin. mGluR2 hybridization was reduced in experimental animals $(B)$ relative to control animals $(A)$. Arrows indicate representative neurons. Scale bar, $30 \mu \mathrm{m}$. 

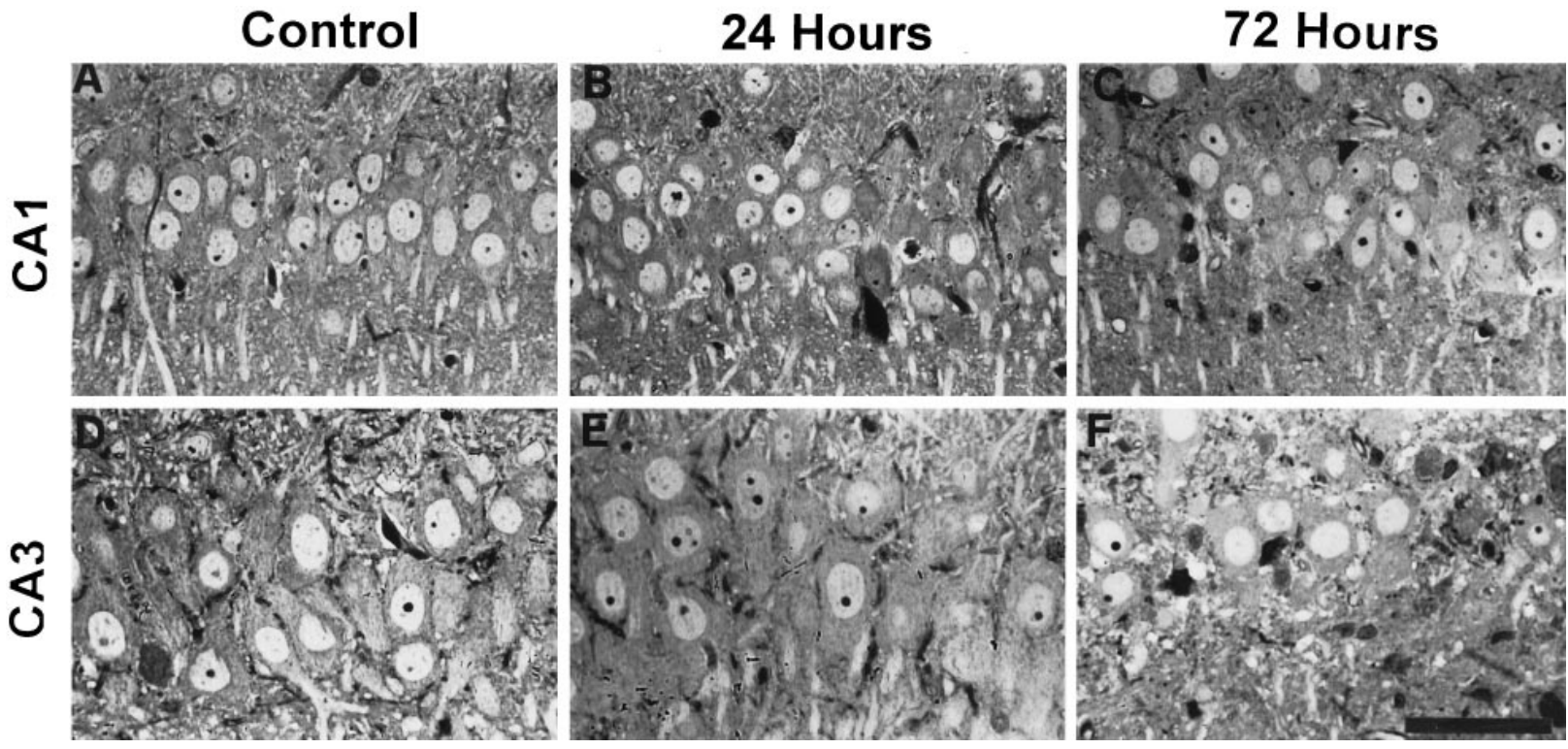

Figure 7. Status epilepticus induces selective, delayed neuronal cell loss in the adult hippocampal CA3. Toluidine blue labeling of coronal brain sections at the level of the dorsal hippocampus from control $(n=8 ; A, D)$ and experimental P40 rats at $24 \mathrm{hr}$ after status epilepticus $(n=4 ; B, E)$ revealed no detectable neuronal damage. At $72 \mathrm{hr}$ after status epilepticus $(n=4)$, cell loss was observed, primarily in CA3 $(C, F)$. Status epilepticus was induced by kainic acid injection, as described in Materials and Methods. Scale bar, $50 \mu \mathrm{m}$.

the developmental stage. Definitive demonstration of changes in receptor protein expression awaits direct measurement of mGluR2 subunit expression.

Resistance to kainate-induced cell death in the hippocampus of young rats has been attributed to a number of factors. Mossy fiber innervation of CA3 pyramidal neurons and of hilar neurons does not mature until the fourth postnatal week (Nitecka et al., 1984; Ribak and Navetta, 1994), which may contribute to the reduced vulnerability of pup CA3 neurons to seizure-induced damage. In addition, expression of the GluR2 AMPA receptor subunit (the subunit that limits $\mathrm{Ca}^{2+}$ permeability) in pup rats is sustained after induction of status epilepticus; in adult rats, GluR2 expression is reduced after status epilepticus (L. K. Friedman, E. F. Sperber, M. V. L. Bennett, S. L. Moshe, and R. S. Zukin, unpublished data). Reduction in GluR2 probably leads to formation of increased numbers of AMPA receptors highly permeable to $\mathrm{Ca}^{2+}$ and therefore increases toxicity of endogenous glutamate (Pellegrini-Giampietro et al., 1991; Bennett et al., 1997; Pellegrini-Giampietro et al., 1997; Gorter et al., 1997).

\section{Significance of downregulation of mGluR2 and upregulation of mGluR4 transcripts}

Immunolabeling indicates localization of mGluR2 to presynaptic mossy fiber terminals, where it is postulated to mediate inhibition of glutamate release by a heterosynaptic mechanism (Shigemoto et al., 1995; Yokoi et al., 1996). Reduction in mGluR2 receptor expression after status epilepticus could thus lead to reduced inhibition of glutamate release, thereby promoting the hyperexcitation associated with severe limbic seizures.

Status epilepticus markedly increases mGluR4 mRNA expression in pup CA3 pyramidal neurons. mGluR4 receptors are thought to be localized to presynaptic membranes. Activation of mGluR4 receptors decreases synaptic currents evoked by afferent stimulation, consistent with a reduction in glutamate release (Baskys and Malenka, 1991; Trombley and Westbrook, 1992). Ultrastructural studies indicate that mGluR4 is localized to pyramidal axon terminals (where it is thought to function as an auto- receptor, mediating inhibition of glutamate release), although it may also be present in cell bodies, apical dendrites, and dendritic spines (Ohishi et al., 1995; Bradley et al., 1996; Kinoshita et al., 1996) (R. Shigemoto, personal communication). Unlike mGluR2, mGluR4 is interspersed among release sites in the presynaptic grid, where it is in a position to couple (through its G-protein) directly to voltage-sensitive $\mathrm{Ca}^{2+}$ channels that trigger neurotransmitter release. Thus, mGluR4 (like mGluR7) may function as an autoreceptor localized to the site of glutamate release. mGluR7 localization can vary along a single axon from one synapse to another and among boutons of a single cell (Shigemoto et al., 1996). This observation raises the possibility that mGluR4 could also be differentially expressed and regulated in axonal arborizations or within spines of the same dendritic shaft.

In the present study, we show that status epilepticus induces an upregulation of mGluR4 mRNA expression in pup CA3. Pyramidal neurons of the CA3 project to CA1 via Schaffer collaterals, to mossy cells in the hilar region, and to neighboring CA3 neurons via recurrent collaterals (Miles and Wong, 1986; Li et al., 1994; Scharfman, 1994). In pup rats, enhanced expression of mGluR4 in the CA3 after status epilepticus could be associated with a greater inhibition of glutamate release from recurrent collaterals, thus affording protection from the ensuing cell death observed in adult CA3 neurons.

\section{Conclusions}

Kainate-induced status epilepticus alters expression of mGluR2 and mGluR4 mRNA in the hippocampus in a cell-specific manner. Because mGluRs are implicated in epileptogenesis and seizure-induced damage, these observations suggest molecular mechanisms that may contribute to the selective vulnerability of adult CA3 pyramidal neurons.

\section{REFERENCES}

Abe T, Sugihara H, Nawa H, Shigemoto R, Mizuno N, Nakanishi S (1992) Molecular characterization of a novel metabotropic glutamate 
receptor mGluR5 coupled to inositol phosphate $/ \mathrm{Ca}^{2+}$ signal transduction. J Biol Chem 267:13361-13368.

Baskys A, Malenka RC (1991) Agonists at metabotropic glutamate receptors presynaptically inhibit EPSCs in neonatal rat hippocampus. J Physiol (Lond) 444:687-701.

Ben-Ari Y (1985) Limbic seizure and brain damage produced by kainic acid: mechanisms and relevance to human temporal lobe epilepsy. Neuroscience 14:375-403.

Behnisch T, Reymann KG (1993) Co-activation of metabotropic glutamate and $N$-methyl-D-aspartate receptors is involved in mechanisms of long-term potentiation maintenance in rat hippocampal CA1 neurons. Neuroscience 54:37-47.

Bradley SR, Levey AI, Hersch SM, Conn PJ (1996) Immunocytochemical localization of Group III metabotropic glutamate receptors in the hippocampus with subtype specific antibodies. J Neurosci 16:2044-2056.

Buisson A, Choi DW (1995) The inhibitory mGluR agonist, S-4carboxy-3-hydroxy-phenylglycine selectively attenuates NMDA neurotoxicity and oxygen-glucose deprivation-induced neuronal death. Neuropharmacology 34:1081-1087.

Catania MV, Landwehrmeyer GB, Testa CM, Standaert DG, Penney Jr JB, Young AB (1994) Metabotropic glutamate receptors are differentially regulated during development. Neuroscience 61:481-495.

Choi DW (1992) Excitotoxic cell death. J Neurobiol 23:1261-1276.

Choi DW (1994) Calcium and excitotoxic neuronal injury. Ann NY Acad Sci 747:162-171.

Dingledine R, McBain CJ, McNamara JO (1990) Excitatory amino acids in epilepsy. Trends Pharmacol 11:334-338.

Friedman LK, Pellegrini-Giampietro DE, Sperber EF, Bennett MVL, Moshe SL, Zukin RS (1994) Kainate-induced status epilepticus alters glutamate and $\mathrm{GABA}_{\mathrm{A}}$ receptor gene expression in adult rat hippocampus: an in situ hybridization study. J Neurosci 14:2697-2707.

Gereau RW, Conn PJ (1995) Multiple presynaptic metabotropic glutamate receptors modulate excitatory and inhibitory transmission in hippocampal area CA1. J Neurosci 15:6879-6889.

Iversen L, Mulvihill E, Haldeman B, Diemer NH, Kaiser F, Sheardown M, Kristensen P (1994) Changes in metabotropic glutamate receptor mRNA levels following global ischemia: increase of a putative presynaptic subtype (mGluR4) in highly vulnerable rat brain areas. J Neurochem 63:625-633.

Kinoshita A, Ohishi H, Nomura S, Shigemoto R, Nakanishi S, Mizuno N (1996) Presynaptic localization of a metabotropic glutamate receptor, mGluR4a, in the cerebellar cortex: a light and electron microscope study in the rat. Neurosci Lett 207:199-202.

Lanthorn TH, Ganong AH, Cotman CW (1984) 2-Amino-4phosphonobutyrate selectively blocks mossy fiber-CA3 responses in guinea pig but not rat hippocampal neurons. Neuron 4:741-749.

Li X-G, Somogyi P, Ylinen A, Buzsáki G (1994) The hippocampal CA3 network: an in vivo intracellular labeling study. J Comp Neurol 339:181-208.

Manzoni O, Bockaert J (1995) Metabotropic glutamate receptors inhibiting excitatory synapses in the CA1 area of rat hippocampus. Eur J Neurosci 7:2518-2523.

McGuinness N, Anwyl R, Rowan M (1991) Trans-ACPD enhances long-term potentiation in the hippocampus. Eur $\mathrm{J}$ Pharmacol 197:231-232.

Meldrum BS (1993) Excitotoxicity and selective neuronal loss in epilepsy. Brain Pathol 3:405-412.

Meldrum BS (1995) Excitatory amino acid receptors and their role in epilepsy and cerebral ischemia. Ann NY Acad Sci 757:492-505.

Miles R, Wong RKS (1986) Excitatory synaptic interactions between CA3 neurons in the guinea-pig hippocampus. $J$ Physiol (Lond) 353:463-504.

Miyamoto M, Ishida M, Shinozaki H (1997) Anticonvulsive and neuroprotective actions of a potent agonist (DCG-IV) for group II metabotropic glutamate receptors against intraventricular kainate in the rat. Neuroscience 77:131-140.

Nicoletti F, Aronica E, Battaglia G, Bruno V, Casabona G, Catania MV, Copani A, Genazzani AA, l'Episcopo MR, Condorelli DF (1994) Plasticity of metabotropic glutamate receptors in physiological and pathological conditions. In: The metabotropic glutamate receptors (Conn JP, Patel J, eds), Totowa, NJ: Humana.

Nicoletti F, Bruno V, Copani A, Casabona G, Knopfel T (1996) Metabotropic glutamate receptors: a new target for the therapy of neurodegenerative disorders? Trends Neurosci 19:267-271.

Nitecka L, Tremblay E, Charton G, Bouillot JP, Berger ML, Ben-Ari Y
(1984) Maturation of kainic acid seizure-brain damage syndrome in the rat. II. Histopathological sequelae. Neuroscience 13:1073-1094.

Ohishi H, Shigemoto R, Nakanishi S, Mizuno N (1993) Distribution of the messenger RNA for a metabotropic glutamate receptor, mGluR2, in the central nervous system of the rat. Neuroscience 53:1009-1016.

Ohishi H, Ogawa-Meguro R, Shigemoto R, Kaneko T, Nakanishi S, Mizuno N (1994) Immunohistochemical localization of metabotropic glutamate receptors $\mathrm{mGluR} 2$ and $\mathrm{mGluR} 3$ in rat cerebellar cortex. Neuron 13:55-66.

Ohishi H, Akazawa C, Shigemoto R, Nakanishi S, Mizuno N (1995) Distributions of the mRNAs for L-2-amino-4-phosphonobutyratesensitive metabotropic glutamate receptors, mGluR4 and mGluR7, in the rat brain. J Comp Neurol 360:555-570.

Paxinos G, Watson C (1984) The rat brain in stereotaxic coordinates, Ed 2. Sydney, Australia: Academic.

Pellegrini-Giampietro DE, Bennett MVL, Zukin RS (1991) Differential expression of three glutamate receptor genes in developing rat brain: an in situ hybridization study. Proc Natl Acad Sci USA 88:4157-4161.

Petralia RS, Wang Y-X, Niedzielski AS, Wenthold RJ (1996) The metabotropic glutamate receptors mGluR2 and mGluR3 show unique postsynaptic presynaptic and glial localizations. Neuroscience 71:949-976.

Pin J, Waeber C, Prezeau L, Bockaert J, Heinemann S (1992) Alternative splicing generates metabotropic glutamate receptors inducing different patterns of calcium release in Xenopus oocytes. Proc Natl Acad Sci USA 89:10331-10335.

Ribak CE, Navetta MS (1994) An immature mossy fiber innervation of hilar neurons may explain their resistance to kainate-induced cell death in 15-day-old rats. Dev Brain Res 79:47-62.

Romano C, van Den Pol AN, O’Malley KL (1996) Enhanced early developmental expression of the metabotropic glutamate receptor mGluR5 in rat brain: protein mRNA splice variants and regional distribution. J Comp Neurol 367:403-412.

Scharfman HE (1994) EPSPs of dentate gyrus granule cells during epileptiform bursts of dentate hilar "mossy" cells and area CA3 pyramidal cells in disinhibited rat hippocampal slices. J Neurosci 14:6041-6057.

Schoepp DD, Conn PJ (1993) Metabotropic glutamate receptors in brain function and pathology. Trends Pharmacol Sci 14:13-20.

Shigemoto R, Nakanishi S, Mizuno N (1992) Distribution of the mRNA for a metabotropic glutamate receptor (mGluR1) in the central nervous system: An in situ hybridization study in adult and developing rat. J Comp Neurol 322:121-135.

Shigemoto R, Wada E, Ohishi H, Takada M, Mizuno N, Roberts JDB, Somogyi P (1995) Differential presynaptic localization of mGluR subtypes mGluR2/3 and mGluR7 in the rat hippocampus. Soc Neurosci Abstr 21:338.20.

Shigemoto R, Kulik A, Roberts JDB, Ohishi H, Nusser, Z, Kaneko T, Somogyi P (1996) Target-cell-specific concentration of a metabotropic glutamate receptor in the presynaptic active zone. Nature 381:523-525.

Simoncini L, Haldeman BA, Yamagiwa T, Mulvihill E (1993) Functional characterization of metabotropic glutamate receptor subtypes. Biophys J 64:A84.

Sperber EF, Haas KZ, Stanton PK, Moshé SL (1991) Resistance of the immature hippocampus to seizure-induced synaptic reorganization. Dev Brain Res 60:88-93.

Tanabe Y, Masu M, Ishii T, Shigemoto R, Nakanishi S (1992) A family of metabotropic glutamate receptors. Neuron 8:169-179.

Tizzano JP, Griffe I, Johnson JA, Fix AS, Hilton DO, Schoepp DD (1993) Intracerebral 1S,3R-1-aminocyclopentane-1,3-dicarboxylic acid $(1 S, 3 R$-ACPD) produces limbic seizures that are not blocked by ionotropic glutamate receptor antagonists. Neurosci Lett 162:12-16.

Tizzano JP, Griffey KI, Schoepp DD (1995) Induction or protection of limbic seizures in mice by mGluR subtype selective agonists. Neuropharmacology 34:1063-1067.

Tremblay E, Nitecka L, Berger ML, Ben-Ari Y (1984) Maturation of kainic-seizure-brain damage syndrome in the rat. I. Clinical electrographic and metabolic observations. Neuroscience 13:1051-1072.

Trombley PQ, Westbrook GL (1992) L-AP4 inhibits calcium currents and synaptic transmission via a G-protein-coupled glutamate receptor. J Neurosci 12:2043-2050.

Yokoi M, Kobayashi K, Manabe T, Takahashi T, Sakaguchi I, Katsuura G, Shigemoto R, Ohishi H, Nomura S, Nakamura K, Nakao K, Katsuki M, Nakanishi S (1996) Impairment of hippocampal mossy fiber LTD in mice lacking mGluR2. Science 273:645-646. 